Terra Brasilis

Terra Brasilis

Revista da Rede Brasileira de História da Geografia e

Geografia Histórica

$7 \mid 2016$

Élisée Reclus e a Geografia dos Novos Mundos

\title{
Élisée Reclus
}

Um geógrafo excepcional

Élisée Reclus : un géographe d'exception

Elisée Reclus: geographer of exception

Béatrice Giblin

Tradutor: David Ramírez Palacios

\section{OpenEdition}

Journals

Edição electrónica

URL: https://journals.openedition.org/terrabrasilis/1924

DOI: 10.4000/terrabrasilis. 1924

ISSN: 2316-7793

Editora

Rede Brasileira de História da Geografia e Geografia Histórica

Refêrencia eletrónica

Béatrice Giblin, «Élisée Reclus», Terra Brasilis [Online], 7 | 2016, posto online no dia 09 dezembro 2016, consultado o 05 dezembro 2022. URL: http://journals.openedition.org/terrabrasilis/1924 ; DOI: https:// doi.org/10.4000/terrabrasilis.1924

Este documento foi criado de forma automática no dia 5 dezembro 2022.

All rights reserved 


\title{
Élisée Reclus
}

\author{
Um geógrafo excepcional \\ Élisée Reclus : un géographe d'exception \\ Elisée Reclus: geographer of exception
}

Béatrice Giblin

Tradução : David Ramírez Palacios

\section{NOTA DO EDITOR}

A presente é a tradução ao português do texto intitulado «Élisée Reclus : un géographe d'exception» da pesquisadora Béatrice Giblin, uma das pioneiras no estudo e uma das mais destacadas conhecedoras da obra deste geógrafo, publicado em 2005 na revista Hérodote, da qual é também diretora ( $n^{\circ} 117$ - Élisée Reclus, 2005. Disponível no site da revista: http://www.herodote.org/spip.php?article148). Agradecemos a autora a sua amável autorização.

"Percorri o mundo como homem livre..."

Em 1981, a Hérodote consagrou já um número a Élisée Reclus: um geógrafo libertário. Por que refazer vinte e quatro anos depois um outro número sobre este grande geógrafo? Não particularmente por gosto das comemorações, pois as manifestações pelo centenário da sua morte têm rendido amplamente e congratulamo-nos com este reconhecimento, embora tardio, da importância deste grande geógrafo, durante muito tempo ignorado e até mesmo totalmente desconhecido para os acadêmicos. Fomos os primeiros a honrá-lo desde o segundo número da revista onde eu escrevi um artigo intitulado «Élisée Reclus: Geografia, anarquismo» seguido de trechos selecionados da parte da Nova Geografia Universal (Nouvelle Géographie Universelle, NGU) sobre a Índia [t. VIII, 1883]. Decidimos consagrar de novo um número a Élisée Reclus porque, em vinte e cinco anos, o tempo passou. Em outras palavras, o mundo tornou-se muito mais complexo desde o colapso da União Soviética e o fim da Guerra Fria. Mesmo antes deste evento, a sociedade comunista já não mais fazia tantas pessoas sonharem. No entanto, 
ainda podia-se imaginar que os princípios eram justos e que era a sua aplicação que era questionável. Nós não estamos mais lá.

2 Lembre-se que já para Reclus o destino do mundo ia jogar-se entre os EUA e a Rússia:

«Pela força das coisas, bem como pela consciência orgulhosa do seu papel entre as nações, os Estados Unidos têm chegado a dispor em todo o mundo ocidental de uma real precedência. Eles são uma república senhora de outras repúblicas, formando, por assim dizer, o contraste, no ordenamento geral do mundo, com o Império Russo, o mais poderoso de todos pela extensão territorial.» [H\&T, t. V, p. 219]

«Os Estados Unidos [são] os rivais na Rússia na pretensão de ser a primeira entre as grandes potências do mundo moderno .» [Ibid., p. 230]

Neste começo do século XXI, são os Estados Unidos os que ganharam. Sabemos que seus atuais dirigentes assim como uma parte da opinião americana estão convencidos de estar investidos de uma missão, ajudar os povos se libertarem da opressão ditatorial de seus dirigentes e instaurar a democracia em todo o mundo, o que só poderia levar à paz, porque todo mundo seria livre. Eis uma visão do devir do mundo que pode parecer próxima àquela de Élisée Reclus, que via na opressão a maior fonte de conflitos, e na liberdade de cada um a garantia de paz para todos, exceto que, para Reclus, anarquista convicto, a opressão começava com a existência de qualquer organização política e administrativa. Esta não é certamente a posição da Hérodote, longe disso. No entanto, apesar desta posição de princípio de Élisée Reclus que explica em parte a fraqueza de algumas de suas análises, acreditamos que é ainda útil se referir à obra deste grande geógrafo.

Deve repetir-se: obra imensa, colossal. Um trabalho excepcional, três grandes obras, a primeira: A Terra: Descrição dos fenômenos da vida do globo (La Terre: Description des Phénomènes de la Vie du Globe); a segunda: a Nova Geografia Universal, 19 volumes escritos por ele só ou com a ajuda de alguns colaboradores, uma publicação que se estende por 18 anos -de 1876 a 1894-, 17873 páginas de texto e 4290 mapas e milhares de gravuras; e finalmente a sua grande obra, 0 Homem e a Terra (L'Homme et la Terre), publicada após sua morte (1905-1908) sob o controle vigilante de seu sobrinho Paul Reclus, um vasto afresco da história da humanidade, de suas lutas e seus progressos, desde a pré-história até o começo do século XX. Reclus estava profundamente comprometido com este trabalho, que ele considerava como a conclusão de toda a sua obra e que ele definiu como uma "obra de geografia social», na qual aborda três temas básicos para ele: a luta de classes, a busca do equilíbrio e o papel primordial do indivíduo, sendo os dois últimos volumes o equivalente a um tratado de geografia humana geral no qual, diferentemente dos sucessores de Reclus, as questões políticas não estão mortas. Que paixão pelo trabalho! Não passava um dia sem que ele escrevesse algumas páginas. Continuamos espantados com a diversidade e amplitude de seu conhecimento, era um grande leitor da imprensa, sabia mais do que seis línguas, viajou enormemente para preparar a NGU e tinha informantes em vários países graças à rede do meio anarquista. Como explicar uma tal capacidade de trabalho, uma constância tal no esforço?

\section{Um ideal político absoluto}

5 Reclus é verdadeiramente levado pelo seu ideal político. Seu trabalho não é só o trabalho de um grande geógrafo, mas é também a obra de um militante, pois deve ficar bem entendido que o seu trabalho de geógrafo não está somente ao serviço da "ciência", mas também ao serviço do seu ideal político, a anarquia tal como a concebia 
Reclus: os homens livres e iguais em uma sociedade sem leis e sem autoridade. Toda a sua vida Reclus será um militante da causa anarquista, ou, tendo em conta a sua personalidade, um ser absoluto, totalmente engajado neste combate por uma sociedade justa e livre. Ele se dá uma missão, trabalhar para seu estabelecimento -mesmo que seja num futuro muito distante- e demostrar que é possível, e a geografia é uma excelente ferramenta para isso.

6 No entanto, o tamanho colossal de sua obra serviu para alguns como argumento para desacreditá-la, sugerindo que Reclus tinha-se dedicado a preencher páginas com descrições de paisagens rapidamente ultrapassadas pelos trabalhos «científicos» dos geógrafos universitários, ao ponto que Vidal escrevia assim em 1908 a Jean Brunhes: «Você sabe quanto a Geografia Universal de Élisée Reclus tem deixado de corresponder ao estado da ciência» [Cf. artigo do Sr. Sivignon p. Xx]. Na verdade, o esquecimento de Reclus repousa sobre outras razões, muito mais sérias e particularmente importantes pela influência que elas tem tido sobre a orientação adotada pela geografia universitária da que Vidal o fundador, este que Yves Lacoste tem claramente demostrado no seu artigo «À bas Vidal? Viva Vidal!» («Abaixo Vidal? Viva Vidal!») [Lacoste, 1979].

7 Digamos de entrada que, para nós, não dá para dissociar o geógrafo do libertário, e que foi a sua pertença ao movimento anarquista o que fechou a ele as portas do reconhecimento da instituição universitária francesa. Se bem a Bélgica mostrou-se mais acolhedora, foi sempre no marco da Universidade Livre de Bruxelas, constituída de livres-pensadores, e a sua vinda tem no entanto apresentado sérias dificuldades. Quando certos membros da universidade anunciaram a sua intenção de convidar Élisée Reclus para ministrar os cursos de geografia, um conflito eclodiu entre os conservadores e os progressistas, conflito que, é verdade, faz muitos anos estava latente. Os conservadores estavam preocupados com as posições anarquistas deste geógrafo internacionalmente conhecido, mais ainda depois daquele ano, 1893, em que teve lugar em Paris um atentado anarquista na Câmara dos Deputados, e opunham-se portanto à sua vinda. Os progressistas decidiram então fundar uma Nova Universidade Livre para que o grande Élisée Reclus pudesse ensinar com toda liberdade e serenidade. Note-se que a sua notoriedade era tal que mais de 1000 pessoas assistiram seu primeiro curso, e precisemos também que Reclus jamais foi remunerado por seu ensino, para ele um seguro de proteção da sua total liberdade de pensar.

Ao longo de toda sua vida, provou sempre uma excepcional força de caráter, e quaisquer que fossem as circunstâncias e as ameaças que pesassem sobre ele, nunca renegou de suas convicções, foi totalmente inflexível quando estimava que a sua consciência estava em jogo, atitude que suscitou a admiração sem limites dos seus partidários e a rejeição daqueles que o qualificavam de «louco» e até de irresponsável. Por exemplo, como estudante sem dinheiro em Berlim, propuseram-lhe uma posição como tutor na casa de um conde «com a condição que eu não fosse republicano, inclinei-me e me recusei» [Correspondance, t. II]. Na verdade, neste traço de caráter, ele era digno filho do seu pai, pastor calvinista, mais místico do que integrista, que tinha escolhido viver da generosidade de uma pequena comunidade protestante de Orthez e renunciado em 1831 a suas funções oficiais de pastor de Sainte-Foy-la-Grande. É inegável que a educação familiar protestante tem influenciado a orientação política dos irmãos Reclus, pois não se pode dissociar a formação e o engajamento político de Élisée daqueles do seu irmão mais velho Élie, pois eles compartilharam sempre os mesmos 
ideais e foram excepcionalmente próximos toda a sua vida. As características principais do protestantismo são a autonomia do indivíduo na sua relação ao dogma e a importância da moral. Dois traços que reencontram-se na ideologia libertária de Reclus, nenhum dogma que respeitar, cada anarquista é livre de pensar como bem entenda, e Reclus por exemplo tem com frequência estado em desacordo com Bakunin (eles se conheceram em 1864) e a liberdade como condição essencial da moralidade. Para os anarquistas nenhuma referência a um dogma de um partido deixaria de significar a alienação da própria liberdade, só conta a sua própria visão do mundo e não alguma imposta por um partido. Nada entre o indivíduo e o vasto conjunto que representa a Humanidade, da mesma forma em que no começo acreditava ainda que não devia de haver nada entre o indivíduo e Deus, de fato, a Humanidade tem de algum modo tomado o lugar de Deus no ideal de Reclus.

Em 1851, Élisée Reclus -com vinte e um anos então- é já profundamente republicano, a revolução de 1848 tem-lhe entusiasmado, é socialista e livre-pensador. Naquele ano, ele seguiu em Berlim o curso do geógrafo alemão Carl Ritter. Numa letra à sua mãe, declara renunciar a proseguir seus estudos de teologia e afirma: «Estou decidido a não seguir senão o grito da minha consciência. Para mim, que aceito a teoria da liberdade em tudo e para tudo, como poderia admitir o domínio do homem num coração que pertence só a deus?» [Correspondance, t. I]. Naquele ano, depois de ter atravessado a França a pé com seu irmão mas velho Élie (guardará sempre uma lembrança prezada desta viagem), redigiu seu primeiro texto político, o Desenvolvimento da liberdade no Mundo (Développement de la liberté dans le Monde), texto reencontrado depois da sua morte e publicado em 1928 em Le Libertaire. Selon Éric Leunis e Jean-Marie Neyts [1985], nessa época Reclus não é ainda realmente anarquista, segundo provam as numerosas referencias cristãs deste primeiro texto político, no entanto encontra-se já uma referência à anarquia:

«Nosso objetivo político em cada nação particular é a abolição dos privilégios aristocráticos, e na Terra inteira é a fusão de todos os povos. Nosso destino é o de atingir um estado de perfeição ideal em que as nações não precisaram mais de estar sob a tutela de um governo ou de uma outra nação; é a ausência de governo, é a anarquia, a mais alta expressão da ordem.»

10 Seu projeto é então o de estabelecer a República cristã, mais tarde, tornado ateu, falará da República universal. Virar ateu, não significa que Reclus tenha perdido aquilo que fazia dele um ser «religioso», pois se não mais acreditava na existência de Deus, acreditava com a fé do carvoeiro na liberdade, condição indispensável para que um dia exista a República universal.

\section{Experiências fundamentais 1851-1857}

11 Após o golpe de Estado do 2 de dezembro de 1851, os dois irmãos, ameaçados de emprisionamento por causa do seu engajamento republicano, exilam-se em Londres. A partir desta data começa para Élisée uma muito longa viagem, pois não retornará à França até 1857.

Esses seis anos são essenciais na afirmação das suas convicções políticas e na sua formação de geógrafo de terreno, mesmo sem ele ter partido com o projeto de tornar-se geógrafo, mas com o de virar agricultor. Descobre assim Londres, depois Irlanda, os Estados Unidos, o México, a América Central, o Istmo de Panamá e por fim a Colômbia, 
na época chamada Nova Granada. Estas experiências foram-lhe fundamentais, na apreensão tanto da desigualdade social quanto das relações de dominação. Em Londres, toma a medida da humilhação que engendra a pobreza, os dois irmãos estão sem dinheiro, Élisée vive escassamente de dar algumas lições, entre outros às jovens L'Herminez, cujos pães são refugiados políticos bastante antipáticos; ele se casará com uma delas depois da morte da sua primeira mulher. Na Irlanda, ele descobre, por uma parte, a pobreza dos irlandeses e da campina irlandesa ainda muito marcada pela Grande Fome (1847), e, por outra parte, a dureza da dominação colonial inglesa. Em 1853, embarca para a Louisiana, onde é confrontado a uma nova situação de dominação, a sociedade escravagista dos plantadores. Revoltado pela condição dos escravos, será um partidário indefectível dos nortistas durante a Guerra de Secessão.

Estas experiências ancoraram assim definitivamente do lado dos mais fracos e confirmaram-lhe o fato que a dignidade do indivíduo está ligada à sua liberdade, que nada pode nem deve alienar.

14 Estas viagens deram-lhe também a oportunidade de descobrir novas paisagens, imensas como nos Estados Unidos, em meios naturais até então desconhecidos no trópico. $\mathrm{Na}$ sua correspondência com a família, da para perceber que ele tem tanto interesse pelo funcionamento da sociedade escravagista quanto pela descoberta do Mississipi, que ele chega a ascender até Chicago, e diz também quanto ele está impressionado pela imensidade do lago Michigan. Assim, seus cadernos de viagem são preenchidos com suas observações sobre o funcionamento das sociedades que ele descobre e sobre as paisagens atravessadas. Ele também escreveu para sua mãe:

«Primeiro, ver a terra, que é para mim estudá-la; o único estudo verdadeiramente sério que eu posso efetuar e o da geografia, e acho que vale muito mais observar a natureza nela mesma do que imaginá-la do fundo do gabinete. [...] para conhecer, é preciso ver. Tinha bem lido algumas frases sobre o mar dos Trópicos, mas não compreendi até que vi com meus próprios olhos suas ilhas verdes e suas sendas de algas, seus longos desfiles de ousados nautilus e seus grandes mantos de luz fosforescente. Eis por que anseio ver os vulcões da América do Sul.» [Correspondance, t. II, p. 109]

Diz também: «estou grávido há muito tempo de uma criatura geográfica que quero trazer ao mundo em forma de livro - já tenho rabiscado bastante; mas isso não é suficiente, eu quero também veros Andes para jogar um pouco da minha tinta sobre sua neve imaculada» [Correspondance, t. II, p. 113].

No entanto, ele não se vê ainda totalmente como um geógrafo, seu projeto naquele momento é o de instalar-se na América do Sul como agricultor e fazer vir atrás dele seu irmão Élie e a sua esposa. Ele parte então para a Colômbia no fim do ano de 1855 atravessando o México e a América Central. Lá, ele procura por dois anos instalar-se como plantador de bananas ou de café. É surpreendente que Élisée Reclus tenha tido tal projeto, ser um colono, mas devemos colocá-lo no contexto da época. Tinha então uma corrente muito favorável às colônias de povoamento, ou seja, à instalação definitiva de colonos em regiões pouco povoadas, pouco desmatadas. Dá para imaginar que esses colonos contribuíram para o desenvolvimento de terras férteis que a população local, muito pouco numerosa, teria negligenciado até então. Esta forma de colonização é apoiada pelo movimento anarquista, pois ela representa o desenvolvimento da natureza pelo homem, o que é considerado como algo muito positivo, desde que haja sensatez suficiente para não fazer bobagens. Reclus, na Irlanda, tinha já trabalhado no desenvolvimento de uma granja agrícola, e tinha apreciado o trabalho da terra. Ele 
tentou então várias vezes instalar-se como plantador na Colômbia, mas descobre que o desenvolvimento no meio tropical não é tão fácil quanto a abundância da vegetação fazlhe supor. Pouco dotado para os negócios e sem capitais suficientes para criar sua exploração, o fracasso é total. Deixou a Colômbia em 1857 graças ao dinheiro enviado por seu irmão mais velho que lhe permitiu pagar as suas dívidas e sua passagem de retorno. Em compensação, ele descobriu o meio tropical, a luxuria da vegetação, a fragilidade dos solos, as febres, ele mesmo havendo estado gravemente doente. Dessa maneira, ele aprendeu muito sobre a diversidade dos meios naturais, das culturas, e enegreceu muitos cadernos de viagem.

\section{A Geografia, uma «ciência verdadeiramente útil»}

17 De volta a Paris, conseguiu em 1858 fazer-se apadrinhar para ser nomeado membro da Sociedade de Geografia, sociedade particular que reúne exploradores e homens de negócios interessados por conhecimentos que possam ser-lhes úteis na expansão dos seus assuntos comerciais. Desta forma, Élisée Reclus ganha aceso à única biblioteca geográfica de Paris. Orienta-se assim cada vez mais à direção da geografia e vê-se a si mesmo cada vez mais como professor de geografia, como escreve à sua mãe: «Sou feliz quando falo de geologia, história, de ciências verdadeiramente úteis; a ideia da possibilidade de virar professor de geografia me enche de alegria»; ou jornalistageógrafo: «Meu orgulho não sofreria em nada por ter que assinar artigos sobre o Mississípi ou sobre a Serra Nevada». Explora as notas tomadas no curso da suas viagens e publica seus primeiros artigos geográficos, mas também políticos, principalmente na Revue des deux mondes (Revista dos dois mundos): «La Nouvelle Grenade, paysages de la nature tropicale» (" A Nova Granada: paisagens da natureza tropical», 1859), «Le Mississipi et ses affluents» («O Mississípi e seus afluentes», 1859), «De l'esclavage aux Étas-Unis» («A escravidão nos Estados Unidos», 1862), «Le coton et la crise américaine» («O algodão e a crise americana», 1862). Em 1861 publica a sua primeira obra com Hachette, Voyage à la Sierra Nevada de Sainte Marthe (Viagem à Serra Nevada de Santa Marta). Tinha sido contratado por esta casa editora em 1859 para redigir as guias de viagem Joanne, antepassados das guias azuis, o que o leva a viajar por numerosas regiões francesas, em particular o Sul, os Pirineus, o País Basco, as Cidades d'Água, etc., e na Europa: Alemanha, Itália, Espanha, Inglaterra (várias vezes), Bélgica, Países Baixos, Suíça. Está encantado, e parte durante meses, muitas vezes no verão, sem se preocupar demasiadamente com a sua jovem esposa e a com a sua filha. Note-se que para desposar esta mulher, Reclus aceita e esta foi sem dúvida a única vez, derogar um dos seus princípios. Ele que rejeita toda lei posta pelo Estado, aceita no entanto o casamento civil, em 1858, pois tinha que ter esta jovem mestiça, «uma bela e jovem mulata conhecida em algum momento durante seus anos de faculdade», segundo seu sobrinho Paul, filho de Élie. Ela era filha de um capitão de longa data originário de Sainte-Foy-laGrande e de uma senegalesa, sendo esta sem dúvida para Élisée Reclus uma das formas mais doces de colocar as suas ideias em prática, ele que era um fervente partidário da mistura das raças. Posteriormente, a pesar de sua segunda esposa provir de um meio bastante burguês, ele impõe a união livre, o que a sua sogra dificilmente consegui lhe perdoar!

Nesta época, começou também a redigir seu primeiro grande livro A Terra: descrição dos fenômenos da vida do globo (La Terre, description des phénomènes de la vie du globe), 
publicado em 1868 (o primeiro volume) e em 1869, o segundo, publicado por Hachette, e que foi um imenso sucesso (de pelo menos dez edições).

o prefácio da primeira edição é revelador a um tempo da sua conceição da geografia e da sua personalidade:

«O livro que hoje aparece comecei-o faz quase quinze anos, não no sossego do gabinete, mas na natureza libre. Foi na Irlanda, no cume de um morro que domina as corredeiras do Shanon, seus ilhotes vibrando sob a pressão das águas e o negro desfiladeiro de árvores em que o rio penetra e desaparece depois de um brusco desvio. Deitado sobre a erva, do lado de um resto de muralha que antanho foi uma fortaleza e que as humildes plantas tem demolido pedra por pedra, desfrutava suavemente dessa imensidade de coisas que manifestavam-se mediante o jogo da luz e das sombras, do estremecimento das árvores e o murmulho da água chocando contra as rochas. Foi ali, nessa primorosa paisagem, onde nasceu em mim a ideia de relatar os fenômenos da terra. E, sem tardança, esbocei o plano da minha obra. Os raios oblíquos de um sol de outono douravam essas primeiras páginas e faziam tremer sobre elas a azulada sombra de um arbusto agitado.

Desde então não tenho deixado de trabalhar nesta obra nas diversas regiões onde o amor às viagens e os azares da vida conduziram-me. Tive a felicidade de ver com meus próprios olhos e de estudar no próprio lugar quase todas as cenas de destruição e de renovação, avalanchas e desaparição de rios, cataratas, inundações e degelos, erupções vulcânicas, surgimento de bancos de areia e de ilhas, trovões, furacões e tempestades. Não é unicamente aos livros mas a terra mesma eu me dirigi para obter o conhecimento da terra. Depois de longas buscas entre o pó das bibliotecas, voltava sempre à grande fonte e reanimava meu espírito no estudo dos fenômenos mesmos. As curvas dos arroios, os grãos de areia das dunas, as ondulações da praia, não me ensinaram menos que os meandros dos grandes rios, os poderosos alicerces dos montes e também a superfície imensa do oceano.

E não é tudo. Posso dizer com o sentimento do dever cumprido que para conservar a nitidez do meu ponto de vista e a probidade do meu pensamento, tenho percorrido o mundo como homem livre, tenho contemplado a natureza com mirada cândida e altiva, recordando que a antiga Freia era ao mesmo tempo a deusa da Terra e a da Liberdade.» (1 de novembro de 1867)

Trata-se então de descrever e de explicar o funcionamento da Terra. De onde vem seu interesse por aquilo que posteriormente chamará de geografia física? Sem dúvida da sua grande sensibilidade às paisagens, manifestada muito cedo, e particularmente às paisagens de montanha, sendo também um notável e infatigável escalador, o que é um ponto comum para muitos geógrafos. Há com certeza um grande prazer em subir passo a passo o sendeiro e ver a paisagem mudar aos poucos com a altitude, para, uma vez no topo, abranger uma vasta paisagem, satisfação de todo escalador que alguma vez experimenta esta posição de dominação, que acrescenta-se para o geógrafo ou o geólogo ao prazer de saber como esta paisagem está construída. Dotado de um real talento de escritor, Élisée Reclus consegue fazer ver as paisagens que ele percorre, e mostra grande prazer em descrever as cores, as luzes, a natureza dos solos. Esta descrição da paisagem do Shannon é, como temos visto, extremamente vívida, deixanos ver a velocidade da água, o jogo das luzes nas árvores, na água, ouvir o som da água que corre, mas também a perceber os tempos, componente essencial da formação das paisagens, evocando as humildes plantas que tem pacientemente demolido uma fortaleza. Esta notação traduz um aspecto da sua filosofia da natureza, Reclus persuadese da potência da natureza que, inexoravelmente, prossegue sua ação. Nesta primeira obra apresenta a Terra como um meio dinâmico, constantemente em movimento, eis por que ele presta grande atenção aos fenômenos de erosão e a outros processos tão ativos como erupções vulcânicas (ele assiste a erupção do Etna em 1865), tremores de 
terra, furações, ou a outros muito mais lentos, menos espetaculares, que afetam territórios muito menores, como escreveu ele, as ondulações da praia tem-lhe ensinado tanto quanto os meandros dos grandes rios.

Por que ele sente a necessidade de concluir seu prefácio com esta referência à Liberdade (à sua: «percorri o mundo como homem livre»), e de associar a Terra à Liberdade? Eu mostrei [Giblin, 1976] a concepção que os anarquistas tinham da natureza, conceição compartilhada por Élisée Reclus. A natureza é um todo equilibrado, e o homem um dos seus elementos - «o homem é a natureza tomando consciência dela mesma», escreveu na primeira capa de L'Homme et la Terre (O Homem e a Terra)-, que deve procurar manter-se em contato com ela e evitar toda ruptura que possa entranhar seu próprio desequilíbrio mas também a perda da sua liberdade. Desta forma, o homem não deve obedecer mais do que as leis naturais (Élisée Reclus chegará a escrever que «a covardia por excelência é o respeito das leis»!). Termina a sua obra sobre a Terra com um capítulo intitulado «A Terra e o homem» que relembra os laços estreitos que os unem:

«O homem, este "ser razoável" que ama tanto vangloriar-se de seu livre arbítrio, não pode no entanto se tornar independente dos climas e das condições físicas do país que habita. Nossa liberdade, em nossas relações com a Terra, consiste em reconhecer suas leis e assim conformar nossa existência. Independentemente da relativa facilidade de maneiras que para nós tem conquistado nossa inteligência e vontade próprias, não deixamos de ser produtos do planeta: adjuntos a sua superfície como imperceptíveis animálculos, somos carregados em todos seus movimentos e dependemos de todas suas leis.» [La Terre, t. II, p. 622]

Citação que facilmente pode reencontrar-se sob a pluma de um ecologista de hoje. Como escrevi em 1981, Reclus é um ecologista antes de tempo e de algum modo uma sorte de precursor do desenvolvimento sustentável, pois ele não sonha em absoluto com uma natureza virgem, poupada de toda ação humana; para ele, o homem pode exercer uma ação benéfica sobre a natureza se sabe agir segundo as leis que ela impõe. Insiste já na sua primeira obra, La Terre, mas principalmente na última, L'Homme et la Terre (O Homem e a Terra), no fato que se deve analisar o meio como um todo:

«É certamente indispensável estudar à parte e de uma maneira detalhada a ação especial de tal ou tal elemento do meio, frio o calor, montanha ou plano, estepe e floresta, rio ou mar, sobre determinado povoado; mas é por um esforço de abstração pura que nós engenhamos a forma de apresentar um traço particular do meio como se ele existisse distintamente, e que procuramos isolar de todos os outros para estudar à sua influência essencial.

Mesmo lá onde esta influência manifesta-se em forma absolutamente preponderante nos destinos materiais ou morais de uma sociedade humana, ela não deixa de entremesclar-se a uma multidão de outras motivações, concomitantes ou contrárias em seus efeitos. 0 meio é sempre infinitamente complexo, e o homem é em consequência solicitado por milhares de forças diversas movimentando-se em todos os sentidos, juntando-se umas às outras, diretamente algumas, outras seguindo ângulos mais ou menos oblíquos, ou contrariando mutuamente sua ação.» [H\&T, t. I, p. 114-115]

23 A integração dos homens aos ecossistemas é diversa: algumas vezes é excelente, algumas vezes é «patológica», segundo a expressão do próprio Reclus. Neste sentido, Reclus é muito mais circunspecto acerca das consequências de algumas grandes obras, sem ser sistematicamente contra, pelo contrario. Assim ele escreve: «Cabe aos homens completar a obra da natureza, imitando nos seus trabalhos alguns dos meios que ela emprega» [La Terre, t. II, p. 261]. 
24 No entanto, homem do seu século, Élisée Reclus está, como outros, fortemente influenciado pela ideia que os climas e os relevos condicionam o caráter da população: os montanheses são vigorosos e resistentes, e os habitantes dos meios tropicais são mais preguiçosos pois a natureza oferece-lhes tudo, sendo o ideal o meio temperado, como o prova o nível de desenvolvimento das populações. Da mesma forma, ele está convencido do equilíbrio harmonioso inerente aos arranjos naturais, ideia que será retomada por muitos geógrafos depois dele e que ainda não tem desaparecido totalmente em certos meios ecologistas. Para Reclus, a arquitetura do relevo cria microclimas separados uns dos outros por montanhas, rios ou litorais, que devem ser respeitados, o que o Estado não faz pois ignora essa organização geográfica natural. Eis o porquê, para o geógrafo, é preciso achar a organização geográfica natural:

«Certamente, as divisões políticas tem um valor transitório, que não é permitido ignorar, mas nas descrições que vão seguir tentaremos de ater-nos principalmente às divisões naturais, tais como são-nos indicadas ao mesmo tempo pelo relevo do solo, a forma das bacias fluviais e o agrupamento das populações unidas pela origem e pela língua. Além disso, estas divisões em si perdem sua importância em países como a Suíça, onde habitantes de raças diversas e que falam idiomas diferentes unem-se num feixe pelo mais forte dos laços: o desfrute da liberdade.» [NGU, t. 1, p. 30]

Desde este ponto de vista e somente desde este ponto de vista, a concepção de geografia de Élisée Reclus não difere tanto daquela dos seus sucessores dedicados a descrever as regiões naturais reunidas num mesmo Estado dentro limites evidentemente políticos, dos quais os geógrafos na sua grande maioria não falavam pois este domínio era reservado aos historiadores. Lembre-se do grande historiador Lucien Febvre, que afirma no seu livro La Terre et l'evolution humaine (A Terra e a evolução humana): «O solo, não o Estado: eis o que deve relembrar o geógrafo». Assim, as famosas regiões naturais foram por longo tempo consideradas por muitos geógrafos como as regiões "verdadeiras», que teriam de servir de marco à organização regional dos Estados, como se as formações naturais, geralmente geológicas, possuírem virtudes tais que o desenvolvimento econômico e social de cada uma delas só pudesse combinar-se harmoniosamente com o das outras. Assim, os sucessores de Reclus têm de certa forma conservado da geografia reclusiana aquilo que é menos relevante, a representação dos méritos duma ordem natural. $\mathrm{Na}$ época de Élisée Reclus são as bacias fluviais as que aparecem como o marco ideal de organização regional; em seguida os geógrafos outorgarão às regiões naturais as caraterísticas mais complexas e a paisagem terá um grande lugar.

\section{Um geógrafo anarquista}

Reclus usa os conhecimentos geográficos para demostrar que o ideal anarquista do «pão para todos» é perfeitamente possível, pois os recursos são largamente suficientes e só a sua desigual e injusta repartição explica a miséria das maiorias.

Aliás, para Reclus o homem deve viver livre, sem obedecer outras leis que não as da natureza e sem sofrer qualquer fiscalização, apenas a livre associação dos indivíduos é aceitável. Eis por que ele deseja a desaparição completa de todas as organizações políticas ou administrativas territoriais, que exprime numa intervenção no congresso da Liga da Paz e da Liberdade (da qual Bakunin é também um dos membros): 
«Eu demonstrei assim que depois de ter destruído a velha pátria dos chauvinistas, a província federal, o departamento e o distrito, máquinas de despotismo, o cantão e a comuna atuais, invenções dos centralizadores ao extremo, não resta mais do que o indivíduo e cabe a ele associar-se como bem entenda: eis a justiça ideal.» [Correspondance, t. I, p. 285]

É este engajamento inabalável neste combate pela liberdade que o leva, por uma parte, a apoiar as ações militantes anarquistas, incluindo as mais violentas, como os atentados:

«Acredito que toda opressão exige a reivindicação, e todo opressor, individual ou coletivo, expõe-se à violência. Quando um homem isolado, levado pela cólera, vinga-se contra a sociedade que tem-no malcriado, malnutrido, mal-aconselhado, o que podemos dizer? Tomar partido contra o infeliz para justificar assim em forma indireta todo o sistema de vilania e opressão sobre ele e sobre milhões de semelhantes, jamais.

Minha obra, meu objetivo, minha missão, é consagrar toda a minha vida a fazer cessar a opressão.»

Mas, por outra parte, a denunciar todas as relações de dominação, seja a exercida pelo Estado, pelos capitalistas, pelos ricos sobre os pobres ou mesmo dos pobres sobre outros pobres, de uma nação dominada sobre uma outra nação mais fraca:

«Não há flagelo comparável àquele de uma nação oprimida que faz recair a opressão como um furor de vingança sobre os povos que por sua vez lhe servem. A tirania e a opressão escalam-se, hierarquizam-se.» [H\&T, t. I, p. 281]

A inflexibilidade das suas convicções, e isto até sua morte, prova quão Élisée Reclus tinha fé na sua justeza, e abdicar teria sido para ele perder a sua dignidade de homem. Ele demonstrou esse compromisso com uma intransigência semelhante à do seu pai na sua prática religiosa, e há, aliás, neste engajamento uma parte de absoluto, algo de religioso. Mesmo tornado ateu, Élisée Reclus mantem-se um homem de fé, mas o credo da liberdade têm de alguma forma substituído o credo religioso. Seu projeto não é o de inventar uma sociedade ideal, utópica, interessa-lhe mudar verdadeiramente o mundo, fazer saltar as múltiplas formas de opressão que entravam o desenvolvimento do homem numa sociedade justa. Eis por que para ele é precisso compreender e explicar o mundo tal como ele é e da maneira mais rigorosa para compreender os mecanismos da opressão que impedem a instauração de uma sociedade mais libre e portanto mais justa. Élisée Reclus mostrou em seu trabalho de geógrafo um notável rigor, tanto mais quanto esse trabalho deve servir para demostrar a correção do seu ideal político; a causa é tão nobre, é tão grande, que está fora de questão disfarçar a realidade, o que poderia contribuir para negar o valor do seu engajamento político. o que torna interessante, ainda hoje, a leitura da obra de Reclus, são as passagens em que ele aborda as relações de poder e/ou dominação. É nisto que Reclus é um precursor, e assim permaneceu durante muito tempo. Não que fosse necessário ser anarquista para abordar estas questões, longe disso, mas Reclus é verdadeiramente uma exceção, pois deve-se lembrar que nessa época eram principalmente os meios burgueses os que se interessavam pela geografia. Assim, os membros das sociedades de geografia pertenciam seja ao meio dos sábios (raramente provenientes das classes populares), seja à alta burguesia (representantes do comércio, da indústria, dos meios coloniais) e mesmo à aristocracia, como na Inglaterra e na Bélgica, onde famílias reais forneceram um apoio generoso a estas sociedades de sábios. Felizmente, Reclus teve chance de ser aceito bem cedo na Sociedade de geografia, tinha então 28 anos -e ainda ignoramos tudo ou quase tudo das suas convicções políticas- se não ele não teria jamais sido 
apadrinhado! Da mesma forma, no momento da Comuna, a sua sorte é a de já ter adquirido uma real notoriedade. Já dizemos, ele engaja-se fortemente na Comuna de Paris, assiste o inicio da possível concretização do seu ideal político, o povo tomando conta. Mas é rapidamente feito prisioneiro, e condenado à deportação em 1871, e posteriormente ao exílio, graças à intervenção de sábios estrangeiros e a do embaixador dos Estados Unidos em Paris que se lembrava do seu comprometimento com os nortistas.

31 Assim, é essa notoriedade, adquirida com o rápido sucesso da sua obra La Terre, o que vai levar à audácia do Sr. Templier, genro de Louis Hachette (falecido em 1864) e também um dos três parceiros da sociedade Hachette, de fazer-lhe assinar na prisão em 1872 um contrato para redigir uma «Geografia descritiva e estatística». Uma só precaução política foi tomada pelo editor. Reclus comprometia-se a não tocar mais do que «de maneira sucinta e com a maior reserva as questões religiosas e morais». Mas Élisée Reclus não podia respeitar completamente este compromisso, pois, como teria ele podido renunciar às suas ideias ou às suas atividades de militante? Ele se encontra envolvido inclusive nos processos dos anarquistas de Lyon em 1883, e com o príncipe Kropotkin prossegue de fato como chefe da organização. A ação militante de Reclus no seio dos meios anarquistas teve alguma influência negativa sobre os leitores? Isto é possível, pois a venda por fascículos tinha sido satisfatória, mas cai bruscamente nos últimos volumes. É verdade que a publicação da Nouvelle Géographie Universelle levou vinte e dois anos, e, devido à sua pena fácil, Élisée Reclus foi um geógrafo prolixo. Excede em muito os limites previstos: no volume VI, ele não está ainda nem a um terço do seu plano, e no lugar dos 200 fascículos semanais de 16 páginas, que dariam 5 ou 6 volumes de 500 páginas, houve 1061, ou seja 19 volumes de 800 ou 900 páginas! Mas a casa Hachette era incontestavelmente uma grande casa editorial. Alem da conta de Élisée Reclus ter debitado 31 701,15 francos en 30 de setembro de 1894, Hachette "oferece imediatamente dar-lhe uma graciosa liquidação». Reclus pergunta se a Casa não poderia lhe fazer um avanço dos seus direitos sobre os fascículos ainda em estoque; ao mesmo tempo, propõe-lhe vender-lhe sua biblioteca. Foi-lhe respondido:

«Todo ano, daremos-lhe conta dos seus direitos sobre os exemplares vendidos; mas como é de temer-se que isto não represente mais do que uma magra cifra, oferecemos pagar-lhe durante dez anos uma quantia mensal de 833,33 francos, destinada a complementar o que você retirar do produto da venda e de forma a garantir-lhe em todos os casos dez mil francos por ano.

No que concerne ao abandono da sua biblioteca, que você tem nos oferecido, nós desejamos que você a conserve à sua livre disposição. Ela tem para o Sr. um valor que nos não desejamos incluir nas contas, de tal sorte que você possa sempre dispor dela como lhe convenha.

Esperamos que você encontre nestas proposições que lhe encaminhamos a expressão do respeito e da devoção afetuosa que nos inspiram as longas e perfeitas relações que não tem deixado de existir entre nós.»

Élisée Reclus recebeu assim uma renda anual até a sua morte. Em 1900, ficavam ainda 70000 volumes, dois terços tiveram de ser destroçados. Sem dúvida, a Nouvelle Géographie Universelle foi bastante desqualificada pelos escritos dos novos geógrafos -os universitários, e também conservadores, Vidal de La Blache e seus discípulos Gallois, de Martone, etc. Parece mais do que provável que o anarquista militante tenha ajudado a desacreditar o geógrafo de perspicácia surpreendente. É bem por isto que não é possível dissociar o geógrafo, que teve de prover-se de quem sabe quanta serena imparcialidade científica, do militante anarquista, que os representantes da instituição decidiram 
esquecer e fazer esquecer quanto antes. Mas como Reclus poderia ter calado aquilo que constituía o fundamento mesmo do seu compromisso político, a opressão dos outros em todos os níveis, não somente dos poderosos sobre os fracos mas também aquela que os fracos exercem sobre aqueles ainda mais fracos. Este rápido desinteresse pela geografia reclusiana é tanto mais lamentável na medida em que, nos últimos volumes, em particular aquele sobre os Estados Unidos, há passagens admiráveis, de excepcional pertinência e clarividência (cf. o artigo de Fredérick Douzet): o inexorável aumento de poder dos Estados Unidos que anuncia tornar-se rapidamente a primeira potência mundial. É nessas passagens, em que ele mostra a dominação de um povo sobre outro, de uma classe social sobre outra, ou as rivalidades entre dois povos pelo controle de um mesmo território, que as análises reclusianas são de incontestável perspicácia e justificam ser relidas. Eis por que já em 1980 nós tínhamos publicado num número intitulado pontos quentes as análises de Reclus sobre o Afeganistão, que a URSS tinha invadido em dezembro de 1979. Insistimos então no fato que Reclus tinha descrito as divisões das tribos afegãs e a antiguidade dos seus enfrentamentos. Geógrafo, ele sabe outorgar um amplo lugar à história afim de explicar as situações de dominação estabelecidas. Por exemplo, a propósito da Ucrânia, ele retraça a história da região desde a idade média e apresenta um mapa dos seus «deslocamentos históricos».

Não se trata em absoluto de negar o caráter ultrapassado de certas abordagens suas, algumas mesmo chocantes como aquelas a propósito dos judeus, que Reclus apresenta sempre como usurários e açambarcadores. Ele, tão sensível a todas as formas de discriminação, cai no antissemitismo mais primário, caricaturesco de fato, até em L'Homme et la Terre, onde no entanto ele fez questão de cartografar os pogrons da Rússia e de falar do vasto gueto em que o império russo mantinha os judeus. Teremos que aguardar longo tempo antes dos geógrafos abordarem de novo esta questão. Mesmo se na NGU de Reclus uma grande parte do texto é consagrada a descrições que cansam rapidamente o leitor, às vezes inclusive quando fala de cidades, não é possível no entanto negligenciar a parte final de cada capítulo, em que aborda a situação econômica, social e política do Estado estudado. É ali que encontramos aquilo que consideramos ser «boa» geografia, pois se preocupa com as condições de vida, econômicas, sociais, culturais e políticas das populações.

Da mesma forma, deve-se apontar a qualidade de alguns mapas da NGU, em particular as cartas coloridas de página dupla. Só mencionaremos dois exemplos. Interessado na liberdade dos povos, Élisée Reclus está logicamente muito preocupado com a distribuição geográfica e a sua complexidade, como é o caso das populações do que constituía então a Turquia Europeia e as da Europa oriental. Eis porque ele dedica estas páginas duplas coloridas a uma cartografia tão precisa quanto possível da sua repartição com esta ênfase nas populações da Turquia Europeia: «esta carta só pode ter valor aproximado. A maior parte das populações de raças e de línguas diversas estão entremescladas e não justapostas».

O mapa da repartição dos povos da Europa oriental, de Berlim aos Urais, o que ele chama de Rússia Europeia, comporta 36 povos e mostra claramente as imbricações entre eles, e Élisée Reclus tomo cuidado de cartografar, usando pequenas manchas, a distribuição da população judia, estando esta carta dos povos precedendo aquela da densidade. Um outro mapa inesperado numa obra de geografia dessa época, mas lógica tratando-se de um geógrafo anarquista, em preto e branco desta vez, é aquela da 
proporção dos exilados na Sibéria segundo as províncias [NGU, t. V: L'Europe scandinave et russe (A Europa escandinava e russa), p. 899], com este comentário:

«O governador tem o direito de assinalar ao ministro do interior as pessoas que convêm-lhe exilar nas províncias longínquas do império [...], a polícia secreta tem o poder de internar ou de exilar sem julgamento nem provas todos aqueles que the pareçam suspeitos. As vilas do norte são lugares de internamento onde os suspeitos e os condenados políticos são muito numerosos, e encontram-se já em todos os distritos da Sibéria, na Transbaikalia e até na ilha de Sakhalin.» [ibid., p. 898]

\section{Uma abordagem geopolítica lúcida e generosa?}

36

É na sua última obra que as análises geopolíticas mais finas e mais pertinentes são mais numerosas, particularmente nos últimos dois volumes, que abordam o mundo contemporâneo. O que não era feito decerto sem risco, pois Reclus teve algumas dificuldades para encontrar editor. A casa Hachette tinha comprometido-se a publicar a obra que Reclus intitulava então L'Homme, géographie social (O Homem: Geografia Social), mas o sucessor do Sr. Templier incluiu, em 1895, uma condição segundo a qual a natureza das conclusões de Reclus não devia ofender os leitores habituais da casa. A resposta de Reclus foi a de procurar um outro editor, que num princípio foi um editor londrino, e a obra seria publicada primeiro em inglês e depois em francês. Mas, levando em conta o volume da obra e o grande número de mapas, o editor recusa-se. É seu irmão Onésime, também geógrafo, mas longe de ter a qualidade de seu irmão mais velho, que encontra um editor um ano antos da morte de Élisée.

L'Homme et la Terre segue sendo um grande livro, pela análise das lutas econômicas, sociais, políticas e mesmo militares que ali se encontram. Apaixonado pelos progressos atingidos pela ciência e a técnica, ele é também muito consciente das suas consequências negativas tanto para os arranjos naturais quanto para as sociedades. $O$ progresso é, para Reclus, um fenômeno em essência contraditório. Aos progressos, ele opõe os «regressos»: «O fato geral é que toda modificação, por importante que ela seja, realiza-se pela junção ao progresso dos regressos correspondentes» [H\&T, t. VI, p. 531]. Ele percebeu o fenômeno da mundialização da economia e as suas múltiplas consequências:

«O teatro se alarga, abarcando já o conjunto das terras e dos mares; as forças que se encontram em luta em cada Estado particular são as mesmas que se combatem pela Terra toda. Em cada país, o capital procura subjugar os trabalhadores; assim mesmo, no maior mercado do mundo, o capital, crescido desmesuradamente, sem importar-se com as velhas fronteiras, tenta fazer obrar em seu proveito a massa dos produtores e garantir para si todos os consumidores do globo, selvagens e bárbaros quanto civilizados.» [H\&T, t. V, p. 287]

Se bem que não pelo estilo, esse texto poderia ter sido escrito hoje. Ou ainda:

«As industrias de todos os países, treinadas mais e mais na luta da concorrência vital, almejam produzir barato comprando ao preço mais baixo as matérias-primas e os braços que as transformarão [...] Não é preciso os emigrantes chineses encontrarem lugar nas manufaturas da Europa e da América para fazer baixar a remuneração dos operários brancos: basta com que industrias similares àquelas do mundo europeu, de lã e algodão por exemplo, sejam fundadas por todo o Extremo Oriente, e que os produtos chineses ou japoneses sejam vendidos na Europa mesma mais baratos do que as produções locais. A concorrência pode fazer-se de pais a pais através dos mares, e não acontece já com certos produtos em detrimento da Europa? 
Desde o ponto de vista econômico, a reaproximação definitiva entre grupos de nações é um fato de importância capital.» [H\&T, t. VI, p. 12]

\section{BIBLIOGRAFIA}

GILBIN Béatrice, «Présentation», in É. Reclus, L'Homme et la Terre, La Découverte, Paris, 1982, 1998. « Géographie et anarchie : Élisée Reclus », Hérodote, n² 2, 1976.

LACOSTE Yves, « À bas Vidal ? Viva Vidal ! », Hérodote, n 16, octobre-novembre 1979.

LEUNIS E. et NEYTS J. M., « La formation de la pensée anarchiste d'Élisée Reclus », Institut des hautes études de Belgique et la Société royale belge de géographie, Bruxelles, 1985. p. 139-154.

RECLUS Élisée, Correspondance, 1850-1905, Schleicher, 3 vol., Paris, 1911. Nouvelle Géographie universelle, la Terre et les hommes, Hachette, 19 vol., Paris, 1876-1894. , La Terre, description des phénomènes de la vie du globe, Hachette, Paris, 2 vol., 1869. , L'Homme et la Terre, Librairie universelle de Paris, 6 vol., Paris, 1905-1908. 


\section{RESUMOS}

$\mathrm{Na}$ obra imensa de Reclus não pode se dissociar o geógrafo do libertário. Seu projeto não era o de inventar uma sociedade ideal, mas o de realmente mudar o mundo, abolir as múltiplas formas de opressão que impedem o desenvolvimento do homem numa sociedade justa. Era preciso portanto compreender e explicar o mundo tal como ele é. o que torna interessante, ainda hoje, a leitura da obra de Reclus, são as passagens em que ele aborda as relações de poder e/ou dominação. Reclus acreditava na plausível existência de uma sociedade universal, justa, onde cada indivíduo será respeitado e saberá respeitar os outros, em que os homens saberão livrar-se dos opressores, dos monopolistas, entre eles o Estado, fonte de poder e, portanto, de dominação. Esta posição política é a priori totalmente oposta à abordagem da Hérodote, pois a nação e, em menor medida, o Estado, são conceitos que estimamos fundamentais da análise geopolítica. Mas, o que nos reaproxima de Reclus é a vontade de decifrar o mundo com honestidade, de não mascarar, na medida em que se é consciente, aquilo do que não gostamos.

Dans l'œuvre immense de Reclus on ne peut dissocier le géographe du libertaire. Son projet n'est pas d'inventer une société idéale, mais de changer vraiment le monde, de faire sauter les multiples formes d'oppression qui entrave l'épanouissement de l'homme dans une société juste. Il lui faut donc comprendre et expliquer le monde tel qu'il est. Ce qui rend intéressante, aujourd'hui encore, la lecture des œuvres de Reclus, ce sont les passages où il aborde les rapports de pouvoirs et/ou de domination. Reclus croyait en l'existence possible d'une société universelle, juste, où chaque individu serait respecté et saurait respecter autrui une fois que les hommes se seraient débarrassés des oppresseurs, des accapareurs, entre autres de l'État, source de puissance et de pouvoirs, donc de domination. Cette position politique est a priori en totale opposition avec l'approche d'Hérodote puisque la nation et dans une moindre mesure l'État sont des concepts que nous estimons fondamentaux de l'analyse géopolitique. Mais ce qui nous rapproche d'Élisée Reclus, c'est la volonté de décrypter le monde avec honnêteté, de ne pas masquer, dans la mesure où l'on en est conscient, ce qui ne nous plaît pas.

In Reclus' tremendous work, the geographer and the libertarian cannot be dissociated. His project is not to invent an ideal society, but to truly change the world and to abolish the various forms of oppression preventing human beings to blossom in a fair society. Therefore he must understand and explain the world as it is. To this day what makes interesting reading Reclus'works are the excerpts in which he brings forward power relations and/or domination relations. Reclus believed in the possible existence of a universal society, a fair society, in which each individual will be respected and will respect others once oppressors and monopolists of the state, among others, will be rejected as they represent a source of power and thus of domination. This political position is a priori in total opposition with the approach of the review Herodote as the nation and the state are fundamental concepts for a geopolitical analysis. But what brings us closer to Elisée Reclus is the will to decipher the world honestly, and not to hide, in all consciousness, what we dislike.

\section{ÍNDICE}

Mots-clés: Élisée Reclus, géographie, anarchisme

Índice cronológico: 1830-1905

Palavras-chave: Élisée Reclus, geografia, anarquismo

Keywords: Élisée Reclus, geography, anarchism 


\section{AUTORES}

BÉATRICE GIBLIN

Diretora da revista Hérodote 